\title{
TESTING OF PERFORMANCE: INTERNATIONAL VERSUS DOMESTIC PORTFOLIO
}

\author{
Christine Adi Njotosutikto \\ Master of Management, University of Surabaya, Indonesia \\ houseoffancy@gmail.com \\ Putu Anom Mahadwartha \\ Department of Management, University of Surabaya, Indonesia \\ anom@staff.ubaya.ac.id
}

\begin{abstract}
This research investigates performance of portfolio with international portfolio and domestic portfolio. Buttler (2012) and Solnik (1974) explained that diversification of international portfolio will reduce risk of portfolio better than domestic portfolio. To measure performance of portfolio this research uses Treynor, Sharpe and Jensen Alpha. This research uses single index model to formed optimal international and domestic portfolio. Test showed that international portfolio has a better performance than domestic portfolio based on Treynor and Sharpe measurement. However, domestic portfolio has a better performance than international portfolio in higher return (Jensen measurement) and high risk. This research will support and contributes investor's decision to invest on widely diverse portfolio rather than domestic portfolios. The research only uses single index model to form the portfolios and the other methods should discuss further in future research.
\end{abstract}

Keywords: diversification of international portfolio, single index model, home bias.

\section{INTRODUCTION}

There are two known risks that arise in capital market; namely systematic risk and unsystematic risk (Buttler, 2012). Systematic risk is an individual risk of a stock that cannot be eliminated by the diversification of a portfolio (Buttler, 2012)

In forming a portfolio that minimize risk as low as possible, it is necessary to establish an optimal portfolio. Markowitz (1952) said that to form an optimal portfolio, the covariance and coefficient correlation value between negative assets need to be considered. Correlation in international diversification certainly cannot be separated from market integration. Guesmi and Teulon (2014) in their research during the period of January 1996-December 2007 found that Indonesia has low integration or cointegration with regional market (ASIA). The cointegration will benefit investors who diversify their international portfolio among those markets.

Solnik (1974) also pointed out that a diversified portfolio will reduce risk. The risk of a portfolio that consists of various returns will be lower than the individual risk of each asset. The greater the amount of stocks in the portfolio, the smaller the risk will 
become. However, a portfolio risk does not only depend on the number of stocks; but the individual risk of each asset and the risks independence with other assets in the portfolio. So, having stocks from companies who are on the same sector would be riskier than having the one with the different sectors.

Gruvel (1968), Levy and Sarnat (1970) and Solnik (1974) argued that foreign stocks have better diversification benefits. International portfolio diversification will make the risk of a portfolio smaller than domestic portfolio diversification (Solnik, 1974). The creation of an international portfolio will reduce the systematic risk that cannot be eliminated with a domestic portfolio diversification (Buttler, 2012). The optimization of an international portfolio diversification should not be doubted anymore; however according to Sercu and Vanpee (2007), in real life, investors tend to invest on domestic assets only, thus it is called as home bias puzzles (Buttler, 2012).

Kang and Stulz (1997) explained that home bias puzzle happens due to the existence of explicit and implicit barriers on international investment. Explicit barriers are barriers on international investment that can be directly observed and measured. For example, the policy of foreign exchanges transactions limitations. However, explicit barriers have been declining from year to year due to the existence of international tax accords policy and the absence of control over foreign exchange. On the other hand, Kang and Stulz (1997) assessed that implicit barriers are barriers that cannot be observed directly. The two kinds of these barriers are political risk and information asymmetry between domestic and foreign investors.

Abidin et al. (2004) also noted that currency risk has become an important factor to be paid attention onto given the collapse of globally exchange rate systems (The Bretton Wood Agreement) in 1971. The instability of international finance will make the exchange rate fluctuates and become volatile; thus, it will be a risk for investors who have an international portfolio. Solnik (1996) in Abidin et al. (2004) argued that currency fluctuation is not the main component that will affect long-term returns of a portfolio because the depreciation of one currency will offset that currency that is appreciating.

This research will examine whether the performance of an international portfolio that was formed will defeat the performance of a domestic portfolio and whether the performance of an international portfolio that was formed will defeat the market. This research was conducted in 2 periods:

a. Observation Period within $1^{\text {st }}$ of January $2010-31^{\text {st }}$ December 2014. In this period researchers will form an optimal portfolio using monthly historical data of stock prices.

b. Testing Period with the timeframe from January $1^{\text {st }}, 2015-31^{\text {st }}$ December 2015.

In the period researcher will test the portfolio optimization that has been made in the observation period using daily historical data of stock prices.

\section{RESEARCH METHODS}


ICAPM is built on the assumption that returns and risks are based on the home currency of investors. In domestic CAPM, investors have a mean variance efficient market portfolio from risky assets. In IAPM, investors do not only have a globally diversified portfolio consisting of risky assets but also a currency specific hedge portfolio that is similar with the risk-free asset in domestic CAPM; as shown in Figure 2.4. Hedge portfolio consists of risk free domestic and foreign assets. The purpose of hedge portfolio ownership is (Butler 2012, 567) as a store of value (such as risk-free assets in domestic CAPM) and to hedge currency risk from market portfolio.

The international equilibrium risk-pricing relation is more complex than domestic CAPM where the expected return value of an asset is a function of covariance with the world market portfolio. Additionally, due to the existence of exchange risk, additional risk premium is required on risk-pricing relation as a reflection of asset covariance with diverse exchange rates (the currencies betas). If there is $\mathrm{k}+1$ country, then there will be additional $\mathrm{k}$ currency risk premia. The expected return on assets is the total market risk premium with the currency risk premia which is illustrated by the following formula (Solnik 2000,166):

Whereas:

$$
E\left(R_{i}\right)=R_{0}+\beta_{i w} \times R P_{w}+\gamma_{i 1} \times R_{P 1}+\gamma_{i 2} R P_{2}+\ldots+\gamma_{i k} R P_{k}
$$

$R_{0} \quad=$ Risk free interest rate

$\beta_{i w} \quad=$ Sensitivity of asset $\mathrm{i}$ against the market movement

$R P_{w} \quad=$ The world market risk premium $=\mathrm{E}\left(\mathrm{R}_{\mathrm{w}}\right)-\mathrm{R}_{0}$

$\gamma_{i l}$ until $\gamma_{i k}=$ Sensitivity of asset $\mathrm{i}$ against the currencies of 1 until k country

$R_{P 1}$ until $R P_{k}=$ Risk premia on the currencies of 1 until k country

In 1963 William Sharpe put forward a simple way to form an optimal portfolio with a single index model (Tandelilin, 2010). Hartono, 2008 argued that an optimal portfolio will consist of stocks that have ERB (excess return to beta) higher or equal to ERB at the cutoff point. Based on the stock's prices observation, single index model fluctuates in the direction of market price index. When the market price index rises, most securities prices tend to rise (Hartono, 2008). The mathematical equations are as formulated below:

$$
R_{i}=\alpha_{i}+\beta_{i} R_{M}+e_{i}
$$

Whereas:

$R_{i} \quad=$ The return of stock $\mathrm{i}$

$\alpha_{I} \quad=$ The part of stock i return that is not affected by market performance

$\beta_{i} \quad=$ Systematic risk of stock $\mathrm{i}$

$R_{M}=$ Return market index

$e_{i} \quad=$ residual errors 
In analyzing the stocks in the capital market, fundamental analysis needs to be done. There are two methods in fundamental analysis: top-down approach and downtop approach that distinguishes only the sequence. In this research, the fundamental analysis will be performed with top-down approach method. The parameters that are often seen in the analyzing a company is Return on Equity (ROE) which describes the extent to which the a company is able to generate profits for shareholders; Return on Assets (ROA) that describes the extent to which assets owned by a company can generate profits; Earnings per Share (EPS) that represents net profit that is ready to be distributed to shareholders divided by the amount of outstanding shares; Price earnings ratio $(\mathrm{P} / \mathrm{E})$ which is the amount of money that investors need to paid to get every ne rupiah of company's earnings.

To test a portfolio performance, three indicators can be used (Reilly and Brown, 2012; and Verma and Hirpara, 2016):

a. Treynor: Treynor (1965) in Reilly and Brown (2012) devised a method to measure portfolio performance with the consideration of risk factors. Treynor paid attention only to systematic risk alone. The higher the Treynor value gets, the better the portfolio's performance is.

b. Sharpe: Sharpe (1966) in Reilly and Brown (2012) measured portfolio performance using the Capital Market Line (CML) line. The measurement is almost the same as the Treynor, however the risk measured in the Sharpe is the total risk, thus standard deviation ( $\sigma \mathrm{i})$ is used. The higher the Sharpe value the better the portfolio's performance is.

c. Jensen: Measurements (Jensen, 1968) in Reilly and Brown (2012) are based on the Capital Asset Pricing Model (CAPM). Tandelilin (2010) said that Jensen index is the excess return above or below the line of Security Market Line (SML). The higher the Jensen value the better the portfolio's performance is.

The research paradigm used is positivism; which according to Sekaran and Bougie (2013) scientific research needed to be done in order to get facts or truths. In addition, to explain the phenomenon that occurs, observation with measurable scale values (not in the form of emotions, feelings and thoughts) needed to be done. In this study there is a clear value or measurement upon optimal portfolio determinants. The type of research performed is descriptive research where data collection of stock prices was conducted to perform a data processing so that it can described what is the optimal form for a stock portfolio (Sekaran and Bougie, 2013). Also, the research is a comparative one; where it will compare international portfolio with domestic portfolio.

Population and sample in this research are domestic stocks portfolios; in which the population is all stocks in Indonesia and the sample is Indonesian stocks that created an optimal portfolio with single index model method. While on the international stock's portfolios, the population is stocks in Japan, Hong Kong, Indonesia, and Taiwan. Samples in international portfolios are local stocks of each country that have passed the ERB test on a single index model to be put in 
international portfolio. The research performed tests both on domestic portfolio and international portfolio within the period of testing between $1^{\text {st }}$ January 2015 until $31^{\text {st }}$ December 2015. The tests performed are: Descriptive Statistical Test, Jarque Bera Normality Test, Zero Differentiate Test, and Independent sample t-test.

\section{RESULTS AND DISCUSSION}

a. Determining Foreign Countries for the International Portfolio Determining countries to be counted on international portfolio consists of 2 developed countries and 2 emerging countries. Indonesia itself is an emerging country, thus this research must look for another 2 developed countries and 1 emerging country in Asia region that has a low correlation with Indonesia. This research is based on the indexes published by Morgan Stanley Capital International (MSCI). Correlations were counted using the weekly return on stock indexes between 2010 and 2015 downloaded from www.yahoo.finance.com. Weekly price of these indexes are on the currency, namely US Dollar. Correlations were calculated using Microsoft Excel 2013 software.

Table 1

Correlations of MSCI Stock Index Year 2010-2015

\begin{tabular}{cccccccc}
\hline Index & EIDO & EWT & EWM & THD & EWH & EWJ & EWS \\
\hline EIDO & 1 & 0.58167 & 0.68857 & 0.66387 & 0.52821 & 0.40274 & 0.65037 \\
EWT & 0.581668 & 1 & 0.67216 & 0.60247 & 0.68014 & 0.55198 & 0.72117 \\
EWM & 0.688575 & 0.67216 & 1 & 0.62719 & 0.58127 & 0.42864 & 0.72283 \\
THD & 0.663872 & 0.60247 & 0.62719 & 1 & 0.61804 & 0.46337 & 0.69311 \\
EWH & 0.528212 & 0.68014 & 0.58127 & 0.61804 & 1 & 0.53778 & 0.74296 \\
EWJ & 0.402737 & 0.55198 & 0.42864 & 0.46337 & 0.53778 & 1 & 0.55774 \\
EWS & 0.650367 & 0.72117 & 0.72283 & 0.69311 & 0.74296 & 0.55774 & 1 \\
\hline
\end{tabular}

Table 1 is the result of correlations calculation. Index with the lowest correlation with Indonesia (Index code: EIDO) on the merging country category is Taiwan (Index code: EWT) with the value of 0.58167 . While on the developed country category, there are Hong Kong (Index code: EWH) and Japan (Index code: EWJ). Local stocks in these four indexes will be the stocks candidate to be put into the international portfolio.

b. Determining Local Stocks on Every Country After the correlations measurement, this research will pick local stocks on EIDO Index (Indonesia), EWT Index (Taiwan), EWH Index (Hong Kong), and EWJ Index (Japan) to be put into international portfolio. This research used local stocks that are on the MSCI Index Top Ten Constituents list on every country from January to February 2016 with the IPO date during research time period. Stocks from Indonesia consist of Telekomunikasi Indonesia (TLKM), Bank Central Asia (BBCA), Astra 
International (ASII), Bank Rakyat Indonesia (BBRI), Bank Mandiri (BMRI), Unilever Indonesia (UNVR), HM Sampoerna (HMSP), Bank Negara Indonesia (BBNI), and Semen Gresik (SMGR). Stocks from Taiwan consist of Taiwan Semiconductor Mfg (2330.TW), Hon Hai Precision Ind Co (2317.TW), Chunghwa Telecom Co (2412.TW), Mediatek Inc (2454.TW), Formosa Plastic Corp (1301.TW), Cathay Financial Holding (2882.TW), Nan Ya Plastic (1303.TW), Uni-President Ent. (1216.TW), Fubon Financial Holding (2881.TW), and Delta Electronics (2308.TW). Stocks from Hong Kong consist of CK Hutchison Holdings (0001.HK), Hongkong Exch \& Clearing (0388.HK), Sun Hung Kai Properties (0086.HK), CLP Holdings (0002.HK), Power Assets Holdings (0006.HK), Hang Seng Bank (0011.HK), Link Reit (0823.HK), and Hongkong China Gas (0003.HK). Stocks from Japan consist of Toyota Motor Corp (7203), MitsubishI UFJ FIN GRP (8306), Softbank Group Corp (9984), KDDI (9433), Japan Tobacco (2914), Honda Motor CO (7267), Takeda Pharmaceutical (4502), Sumitomo Mitsui Finl GRP (8316), Mizuho Financial Group (8411), and NTT Docomo (9437).

c. Determining Indonesian Local Stocks to Create Domestic Portfolio In determining local stocks that were put in the domestic portfolio, this research does not use Top Ten Constituents MSCI Indonesia (EIDO) due to the lack number of stocks. Thus, this research used all stocks components that created MSCI Indonesia with a consistent presence from May 2010 until January 2016. This research used the fact sheet from January 2016. Those stocks are Telekomunikasi Indonesia (TLKM), Bank Central Asia (BBCA), Astra International (ASII), Bank Mandiri (Persero) (BMRI), Unilever Indonesia (UNVR), Bank Negara Indonesia (Persero) Or (BBNI), Semen Indonesia Persero (SMGR), United Tractors (UNTR), Indocement Tunggal Prakarsa (INTP), Gudang Garam (GGRM), Charoen Pokphand Indonesia (CPIN), Summarecon Agung (SMRA), Ciputra Development (CTRA), Bank Danamon Indonesia (BDMN), PP Persero (PTPP), Adaro Energy (ADRO), Astra Agro Lestari (AALI), PT Bank Tabungan Negara (BBTN), Tambang Batubara Bukit Asam (PTBA), Aneka Tambang (ANTM), Panin Financial (PNLF), Energi Mega Persada (ENRG), Eagle High Plantations (BWPT), Indo Tambangraya Megah (ITMG), Timah, Bumi Resources (TINS), and (BUMI).

While the market used for international portfolio is MSCI ACWI Index that consists of stocks from mid and large cap from 23 developed markets and 23 emerging markets. Historical data of monthly closing price between 2010 and 2014 are used to form a portfolio and daily closing price on 2015 is used for the testing period. On the domestic portfolio, the market used is MSCI Indonesia Index (EIDO) which is an index that consists of stocks from local companies in Indonesia. Data used are historical data of monthly closing price between 2010 and 2014 to form a portfolio and daily closing price on 2015. International portfolio cannot be separated from currency rate. Thus, in this research, historical data of monthly closing currency rate between 2010 and 2014 are used to form a portfolio and historical data of daily closing currency rate on 2015 is used for portfolio testing. 
In forming a portfolio, risk free assets are needed. On domestic portfolio, risk free asset used is Bank Indonesia Interest Rate (Suku Bunga Bank Indonesia or SBI). In forming international portfolio, risk free asset is currency specific hedge portfolio (Buttler 2012,567). The risk-free assets used in this research is Matthews Asia Growth Fund (code: MPACX); which is a mutual fund with the citation as Best Mutual Funds based on U.S News version. This mutual fund diversifies its portfolio on stocks and investment in Asia Pacific countries such as Japan, Indonesia, Hong Kong, India, Philippines, and others (Fact Sheet on Apendix 21). Based on its performance, MPACX also has a higher return than its benchmark. In order to get the risk-free rate value used in the international portfolio, this research used the historical monthly closing price of MPACX mutual fund. While for the testing period, this research used the historical daily closing price of MPACX mutual fund.

\section{d. Forming the Portfolio}

In order to form an optimal portfolio, this research used single index model method where stocks that formed a portfolio are stocks that have excess return to beta (ERB) higher or equal to the value of ERB at the cutoff point (C*) (Jogiyanto, 2008). The forming of international portfolio cannot be separated from the effect of currency risk; thus all the local stocks and the market will be calculated with the same currency. There are two currencies used; namely US Dollar and Indonesian Rupiah. In this section, all currencies that are not US Dollar will be converted onto US Dollar.

Table 2

\begin{tabular}{|c|c|}
\hline \multicolumn{2}{|c|}{ Compositions and International Portfolio Variables in US Dolla } \\
\hline International Portfolio in US Dollar & Values \\
\hline Portfolio Compositions & \\
\hline HMSP & 0.19439 \\
\hline 2412.TW & 0.77987 \\
\hline 2308.TW & 0.02574 \\
\hline Portfolio Variables & \\
\hline Portfolio Beta $\left(\beta_{\mathrm{P}}\right)$ & 0.2447 \\
\hline Portfolio Alpha $\left(\alpha_{\mathrm{P}}\right)$ & 0.01611 \\
\hline $\mathrm{E}(\mathrm{Rp})$ & 0.01837 \\
\hline Portfolio Variance $\left(\sigma_{P}^{2}\right)$ & 0.00017 \\
\hline
\end{tabular}

Based on the calculation of single index model on the forming of international portfolio in US Dollar, this research managed to get the value of $\mathrm{C}^{*}$ equals to 0.004783 on the 2412 .TW stock. On $\mathrm{C}^{*}$, the ERB value was 0.06632 . On single 
index model, an optimal portfolio will be formed with the ERB value higher or equals to ERB value at $\mathrm{C}^{*}$. Thus, an optimal international portfolio in this research is formed from local stocks with ERB value higher or equal to 0.06632 ; they are 2308.TW stock, HMSP, and 2412.TW stock with the composition and portfolio variables as follows on table 2.

Steps taken that resulted in Table 3, 4 and 5 were the same with the steps taken in forming an international portfolio in US Dollar; the only difference is that stock prices were already converted into Indonesia Rupiah from the currency rate data. It is the same with forming a domestic portfolio both in US Dollar and Indonesian Rupiah.

Table 3

\section{Compositions and International Portfolio Variables in Indonesian Rupiah}

\begin{tabular}{lc}
\hline International Portfolio in Indonesian Rupiah & Values \\
\hline Portfolio Compositions & \\
TLKM & 0.05519 \\
ASII & 0.07685 \\
BBCA & 0.04341 \\
BBRI & 0.04781 \\
BMRI & 0.02434 \\
BBNI & 0.0567 \\
SMGR & 0.01531 \\
2330.TW & 0.14016 \\
2412.TW & 0.25611 \\
0006.HK & 0.10656 \\
0823.HK & 0.17755 \\
Portfolio Variables & \\
Portfolio Beta $\left(\boldsymbol{\beta}_{\mathbf{P}}\right)$ & 0.30099 \\
Portfolio Alpha $\left(\boldsymbol{\alpha}_{\mathbf{P}}\right)$ & 0.01828 \\
E(Rp) & 0.0225 \\
Portfolio Variance $\left(\boldsymbol{\sigma}_{\boldsymbol{P}}^{\mathbf{2}}\right)$ & 0.00018 \\
\hline
\end{tabular}

Table 4

Compositions and Domestic Portfolio Variables in US Dollar 


\begin{tabular}{lc}
\hline \multicolumn{1}{c}{ Domestic Portfolio in US Dollar } & Values \\
\hline Portfolio Compositions & \\
TLKM & 0.58563 \\
CPIN & 0.41437 \\
Portfolio Variables & \\
Portfolio Beta $\left(\boldsymbol{\beta}_{\mathbf{P}}\right)$ & 0.9026 \\
Portfolio Alpha $\left(\boldsymbol{\alpha}_{\mathbf{P}}\right)$ & 0.02825 \\
E(Rp) & 0.03519 \\
Portfolio Variance $\left(\boldsymbol{\sigma}_{\boldsymbol{P}}^{\mathbf{2}}\right)$ & 0.00451 \\
\hline
\end{tabular}

Table 5

\section{Compositions and Domestic Portfolio Variables in Indonesian Rupiah}

\begin{tabular}{lc}
\hline Domestic Portfolio in Indonesian Rupiah & Values \\
\hline Portfolio Compositions & \\
TLKM & 0.31806 \\
CPIN & 0.17904 \\
ASII & 0.29741 \\
UNVR & 0.06714 \\
PTPP & 0.13835 \\
Portfolio Variables & \\
Portfolio Beta $\left(\boldsymbol{\beta}_{\mathbf{P}}\right)$ & 0.80629 \\
Portfolio Alpha $\left(\boldsymbol{\alpha}_{\mathbf{P}}\right)$ & 0.02488 \\
E(Rp) & 0.03491 \\
Portfolio Variance $\left(\boldsymbol{\sigma}_{\boldsymbol{P}}^{2}\right)$ & 0.00267 \\
\hline
\end{tabular}

e. The Calculation of Expected Return, Variance, Sharpe, Treynor, and Jensen on the Testing Period

Testing period on 2005 used the historical stocks daily closing price. In line with the forming period, on the testing period, all stocks prices on optimal portfolio are presented using the same the currency which is US Dollar for portfolio that uses US Dollar and Indonesian Rupiah for portfolio that use Indonesian Rupiah.

In this period, the performance of international portfolio that was formed with the period of 2010-2014 will be tested. Thus, the value of portfolio alpha, portfolio beta, and the portfolio compositions resulted from the period of portfolio forming will be used on the testing period. The value of expected return and portfolio variance were resulted from the daily historical data of stocks in the portfolio for a week. Therefore, there are 52 data of expected return values and portfolio variance during the testing period. Portfolio performance was measured with Sharpee, Treynor, and Jensen. 
f. Forming International Portfolio

This research began with determining four foreign countries that will be used for international portfolio. These four countries then divided into two emerging countries and two developed countries. Since international portfolio formed was meant for Indonesian investors, thus Indonesia has become that country that has to be put inside the portfolio. The other three countries were chosen based on the negative correlation between that country's stock index with the Indonesia's stock index; in line with the opinion of Markowitz (1952) that to form an optimal portfolio, it has to be considered that the correlation between assets should be negative.

Correlations between each country were calculated using each country stock index made by MSCI. Based on table 1, there is no stock index with negative correlation to Indonesia MSCI stock index (EIDO), thus this research use stocks with the lowest correlation to EIDO. It was known that Taiwan MSCI stock index (EWT) is the stock index from emerging country with the lowest correlation to Indonesia MSCI stock index with the value of 0.58167 . The stocks from developed countries that have the low correlation with EIDO are Japan MSCI stock index (EWJ) with the value of 0.40274 and Hong Kong MSCI stock index (EWH) with the value of 0.52821 . The international portfolio will consist of stocks from Indonesia, Taiwan, Japan, and Hong Kong. The stock prices used on the portfolio forming period are the monthly adjusted closing prices that have considered dividend payout.

Currency risk has become of the thing that investors with international portfolio must face on, and it has become a considerable factor in International Capital Asset Pricing Model (ICAPM). The instability of international finance will make the exchange rate to fluctuate and be volatile (Abidin et al., 2004). According to Solnik (1996) in Abidin et al. (2004), this fluctuation will not affect portfolio return on the long run. However, considering that the testing period in this research is short; which is only a year (2015), thus researcher will use currency risk as a factor that affects the calculation of portfolio's risk and return. Stock prices used on the forming and research period will be converted into two currencies namely US Dollar as the strongest currency in Asia and Indonesian Rupiah as the investor's home currency (Buttler, 2012). Thus, there will be two kinds of international portfolio: in US Dollar and in Indonesian Rupiah.

The next step, the research forms an optimal portfolio for the international portfolio with single index model method. The market will use the MSCI ACWI index which is an index consisting of mid and large cap stocks from 23 developed markets and 23 emerging markets. Risk free asset will use the Matthews Asia Growth Fund mutual fund (code: MPACX) which is a mutual fund with the title of Best Mutual Funds based on U.S News.

Stocks that formed optimal portfolio are those that formed international portfolio in US Dollar; which are: Taiwan stock Chunghwa Telecom Co (code: 2412.TW), Indonesia stock HM Sampoerna (code: HMSP), and Taiwan stock Delta Electronics (code: 2308.TW). Based on Table 2, stocks that formed optimal international portfolio in US Dollar consist of stocks from Indonesia and Taiwan, namely: HMSP, 
2412.TW, and 2308.TW with the composition of $0.19439,0.77987$, and 0.02574 respectively. The biggest composition of this portfolio is the stock from Taiwan and individual stock with the biggest composition is 2412.TW. The value of portfolio beta $(\boldsymbol{\beta} \mathbf{P})$ is 0.2447 ; portfolio alpha $(\boldsymbol{\alpha P})$ is $0.01611 ; \mathrm{E}(\mathrm{Rp})$ is 0.01837 ; and portfolio variance $\left(\boldsymbol{\sigma}_{\boldsymbol{P}}^{2}\right)$ is 0.00017 .

The steps of forming in international portfolio above were being re-do in forming an international portfolio in Indonesian Rupiah. All stock prices were converted into one currency which is Indonesian Rupiah. The stocks are Taiwan Semiconductor Mfg (code: 2330.TW), Bank Mandiri (code: BMRI), Bank Rakyat Indonesia (code: BBRI), Semen Indonesia (code: SMGR), Bank Central Asia (code: BBCA), Power Assets Holdings (code: 0006.HK), Link Reit (code: 0823.HK), Chunghwa Telecom Co (code: 2412.TW), Bank Negara Indonesia (code: BBNI), Telekomunikasi Indonesia (code: TLKM), and Astra International (code: ASII).

Optimal international portfolio in Indonesian Rupiah consists of stocks from Indonesia, Taiwan, and Hong Kong; which are TLKM, ASII, BBCA, BBRI, BMRI, BBNI, SMGR, 2330.TW, 2412.TW, 0006.HK, and 0823.HK with the composition of $0.05519,0.07685,0.04341,0.04781,0.02434,0.0567,0.01531,0.14016,0.25611$, 0.10656 , and 0.17755 respectively. The composition of the country in this portfolio is more balanced that the one in US Dollar. However, the biggest remains stocks from Taiwan and individual stock with the biggest composition is 2412.TW. The value of portfolio beta $\left(\boldsymbol{\beta}_{\mathrm{P}}\right)$ is 0.30099 ; portfolio alpha $(\boldsymbol{\alpha P})$ is 0.01828 ; $\mathrm{E}(\mathrm{Rp})$ is 0.0225 ; and portfolio variance $\left(\boldsymbol{\sigma}_{\boldsymbol{P}}^{2}\right)$ is 0.00018 .

After the portfolios are formed, the fundamental analysis for each stock need to be done. Based on return on asset (ROA) and return on equity (ROE) data of 2412.TW, 2330.TW, 0006.HK, 0823.HK, and BBCA from 2013-2015, it shows that their value increases along with years. Bigger ROA shows that company's ability in managing their assets to produce profits is getting better. Bigger ROE shows that company's ability in producing profits for their stockholders is getting better. While for TLKM, HMSP, ASII, BBRI, BMRI, BBNI, and SMGR, the value of ROA and ROE tend to decrease along the years due to economic slowdown that happened in Indonesia. The increase on ROA and ROE value of BBCA can be considered as small given that it is only $0.05 \%$. The value of earning per share (EPS) and price earnings ratio (PER) of stocks above tend to increase. The increase in EPS value means that net profit received by stockholders is increasing. While the increase in PER means amount of money that investors have to pay to get every amount of earning.

\section{g. Forming Domestic Portfolio}

The purpose of this research is to compare the performance of international portfolio and domestic portfolio, thus domestic portfolio should be formed as well. Because this research was made based on the interest of Indonesian investors, thus domestic portfolio consists of Indonesian stocks. The domestic portfolio formed did not use Top Ten Constituents MSCI Indonesia (EIDO) like the one in the making of 
international portfolio because the stocks numbers are too little. Stocks used to form a domestic portfolio are stocks that formed MSCI Indonesia index from May 2011 up to January 2016. The stock prices being used on the forming period are monthly adjusted closing prices that have considered dividend payout. As previously explained, international portfolio was formed in both US Dollar and Indonesian Rupiah; thus, domestic portfolio also formed in two currencies namely US Dollar and Indonesian Rupiah. Next, the research will form and optimal portfolio for domestic portfolio with single index model method. As the market, MSCI Indonesia (EIDO) index will be used. Risk free asset will use the interest rate given by Bank Indonesia. Stocks that formed optimal portfolio in the domestic portfolio in US Dollar are Charoen Pokphand Indonesia (code: CPIN) and Telekomunikasi Indonesia (code: TLKM). Based on table 4, it can be seen that stocks that formed optimal domestic portfolio in US Dollar are TLKM and CPIN dwith the composition of 0.58563 and 0.41437 respectively. The biggest composition in this portfolio is TLKM. The value of portfolio beta ( $(\boldsymbol{\beta P})$ is 0.9026 ; portfolio alpha $(\boldsymbol{\alpha} \mathbf{P})$ is $0.02825 ; \mathrm{E}(\mathrm{Rp})$ is 0.03519 ; and portfolio variance $\left(\boldsymbol{\sigma}_{\boldsymbol{P}}^{2}\right)$ is 0.00451 .

Stocks that formed optimal portfolio in the domestic portfolio in Indonesian Rupiah are stocks with ERB value higher or equal to 0.02915; they are Astra International (code: ASII), PP Persero (code: PTPP), Charoen Pokphand Indonesia (code: CPIN), Telekomunikasi Indonesia (code: TLKM) and Unilever Indonesia (code: UNVR). Based on table 5, stocks on optimal domestic portfolio in Indonesian Rupiah consist of TLKM, CPIN, ASII, UNVR, and PTPP with the composition of $0.31806,0.17904,0.29741,0.06714$, and 0.13835 respectively. The biggest composition in this portfolio is TLKM. The value of portfolio beta ( $\beta \mathbf{P})$ is 0.80629 , portfolio alpha $\left(\boldsymbol{\alpha}_{\mathbf{P}}\right)$ is $0.02488, \mathrm{E}(\mathrm{Rp})$ is 0.03491 , and portfolio variance $\left(\boldsymbol{\sigma}_{\boldsymbol{P}}^{2}\right)$ is 0.00267 . Just like what happened on international portfolio, stocks in the domestic portfolio were also fundamentally analyzed. Stocks in the international portfolio will not be analyzed anymore. The economic slowdown in 2013-2015 makes the value of ROA and ROE of CPIN and UNVR decreased; while the ROA value of PTPP increase slightly which is about $0.2 \%$. However, the values of EPS and PER were increasing. The increase in EPS value indicates that earning for every stock was increasing.

h. Portfolio Performance During the Testing Period and the Result of Statistical Data Processing

Parameters of portfolio performance in this research are Treynor, Sharpe, and Jensen. Optimal international portfolio and optimal domestic portfolio that was formed on the period of 2010-2014 will then be tested by calculating Treynor, Sharpe, and Jensen on the testing period of 2015. Stock prices that were used in this testing period are the adjusted daily closing prices that have considered dividend payout.

The test of optimal portfolio will still preserve the compositions, stocks, portfolio beta $\left(\boldsymbol{\beta}_{\mathbf{P}}\right.$, and portfolio alpha ( $\left.\boldsymbol{\alpha}_{\mathbf{P}}\right)$ obtained from the forming period; in line with 
Hartono (2008) who said that the value of $\alpha$ and $\beta$ are constant. The value of expected return, variance, Sharpe, Treynor, and portfolio Jensen were obtained from market daily data and stocks that formed the portfolio in a week during a year long period of trading. Thus, in the testing period of 2015 , there will be 52 data that will be tested statistically.

i. The Comparison of International Portfolio Performance and Domestic Portfolio Performance

Based on the differentiate test performed, there is a difference between the value of Treynor, Sharpe, and Jensen on international portfolio with the value of Treynor, Sharpe, and Jensen on domestic portfolio (paired 1, 2, 3, 6, 7, and 8). Thus, the mean value of these variables descriptive statistic can be used and compared.

Table 6

Comparison Table of Portfolio Variables

\begin{tabular}{ccccc}
\hline \multirow{2}{*}{$\begin{array}{c}\text { Descriptive } \\
\text { Statistic }\end{array}$} & International & Domestic & International & Domestic \\
\hline $\mathbf{E}(\mathbf{R})$ & 0.0161114 & 0.02789 & 0.0183972 & 0.02463 \\
$\boldsymbol{\sigma}_{\boldsymbol{P}}^{\mathbf{2}}$ & $1.075 \mathrm{E}-05$ & 0.00026 & $1.069 \mathrm{E}-05$ & 0.00019 \\
$\boldsymbol{\sigma}_{\boldsymbol{P}}$ & 0.0032787 & 0.01607 & 0.0032689 & 0.01367 \\
$\boldsymbol{\beta}_{\mathbf{P}}$ & 0.2447 & 0.9026 & 0.30099 & 0.80629 \\
$\boldsymbol{\alpha}_{\mathbf{P}}$ & 0.01611 & 0.02825 & 0.01828 & 0.02488 \\
\hline
\end{tabular}

Comparison of International and Domestic Portfolio performance has been summarized in table 6 and 7.

Table 7

Comparison Table of Portfolio Performance

\begin{tabular}{ccccc}
\hline \multirow{2}{*}{ Index } & \multicolumn{2}{c}{ US Dollar } & \multicolumn{2}{c}{ Indonesian Rupiah } \\
& International & Domestic & International & Domestic \\
\hline Tp & 0.06601 & 0.03057 & 0.05968 & 0.03018 \\
Sp & 10.1297 & 2.75542 & 8.19909 & 2.78553 \\
Jp & 0.01614 & 0.02822 & 0.01797 & 0.02483 \\
\hline
\end{tabular}

Treynor index, also called the reward to volatility ratio, is an index that describes how big risk premium of a portfolio is $\left(E\left(R_{P}\right)-\overline{R B R}\right)$ compared to systematic risk of portfolio $(\beta \mathrm{P})$. Portfolio risk premium is the compensation that investors get for having risk in their portfolio (Tandelilin, 2010). The concept of Treynor index calculation is based on security market line (SML). The greater the value of Treynor, the better the portfolio performance will be. It can be seen from Table 8 that the Treynor value of international portfolio is greater than the Treynor value of domestic 
portfolio both is US Dollar and Indonesian Rupiah. This means that the performance of international portfolio from the point of Treynor index is better than the performance of domestic portfolio. From Table 6 it is known that the expected return of domestic portfolio is bigger than the international portfolio both in US Dollar and Indonesian Rupiah, however the measurement of portfolio performance is not only based on expected return but also from risk. On the Treynor index, risk is measured by portfolio beta. On Table 6 the domestic portfolio beta is larger $(0.9026$ and $0.80629)$ than the international portfolio beta ( 0.2447 and 0.30099$)$.

Based on the analysis of Sharpe index that can be seen from table 7, the Sharpe value of international portfolio is bigger than the Sharpe value of domestic portfolio both in US dollar and Indonesian Rupiah. Sharpe index that is also called with reward to variability ratio is the index that measures the portfolio risk premium compared to standard deviation of portfolio. The concept of Sharpe index calculation is based on capital market line (CML). The greater the Sharpe value gets; the better portfolio performance is. Thus, it can be concluded that international portfolio performance is better than domestic portfolio performance both in US Dollar and Indonesian Rupiah from Sharpe index point of view. Even though based on table 6 that the value of domestic portfolio expected return is greater than international portfolio expected return; however, the value of domestic portfolio standard deviation is also greater than the value of international portfolio standard deviation.

From Table 7, Jensen index of international portfolio and Jensen index of domestic portfolio have a positive value. This indicates that there are excess returns in both portfolios. Jensen index measures the difference between portfolio expected return with the expected return if portfolio is on the security market line (SML) (Tandelilin, 2010). The greater Jensen index gets, the greater portfolio return on certain systematic level gets. It can be seen from Table 7 that Jensen index value of international portfolio is smaller than Jensen index value of domestic portfolio. Thus, it can be said that domestic portfolio performance is better than international portfolio performance from Jensen index point of view.

Based on all the analysis of Treynor index, Sharpe, and Jensen; it can be concluded that international portfolio performance both in US Dollar and Indonesian Rupiah is better than the domestic one based on the point of view of portfolio return performance compared to its risk. While if it is seen from return only, then domestic portfolio performance is better than international portfolio performance because the value of Jensen on international portfolio is smaller than the value of Jensen on domestic portfolio; which indicates that domestic portfolio has a greater return than international portfolio. However, it must be considered that the risk of domestic portfolio is greater than the risk of international portfolio.

\section{j. Comparison of International Portfolio Performance with Market}

The next research question was whether international portfolio performance can beat the market. To answer this question, this research will compare expected return value of international portfolio with expected return value of the market and the Sharpe 
value of international portfolio with the Sharpe value of market. This research did not use market's Treynor as a measurement because market beta is unknown and usually assumed equals to one. This research believes that is not valid enough, thus it is substituted with market expected return as comparison variable.

Based on the explanation from previous section, market expected return and market Sharpe variables in international portfolio and domestic portfolio both in US Dollar and Indonesian Rupiah are smaller or equal to zero. In addition to the independent test, the value of market Sharpe in international portfolio with market Sharpe in domestic portfolio both in US Dollar and Indonesian Rupiah do not differ at all.

From independent test result on expected return of international portfolio with expected return of market on international portfolio and domestic portfolio paired and Sharpe of international portfolio with Sharpe of international portfolio and domestic portfolio both in US Dollar and Indonesian Rupiah paired, it was stated that there is a difference. Thus, the value of portfolio expected return with market expected return and portfolio Sharpe with market Sharpe can be compared.

Table 8

Comparison of International Portfolio Performance with Market

\begin{tabular}{lccc}
\hline \multicolumn{1}{c}{ Variables } & Dollar & Rupiah & Sig \\
\hline E(Rp) International & 0.06601 & 0.05968 & $* *$ \\
E(Rm) International & $7.45 \mathrm{E}-06$ & 0.0004 & \\
E(Rm) Domestic & -0.0004 & -0.0003 & \\
Sp International & 10.1297 & 8.19909 & $* *$ \\
Sm International & 0.02804 & -0.0399 & $* * *$ \\
Sm Domestic & -0.1505 & -0.1645 & \\
\hline
\end{tabular}

It can be seen from Table 8 that the value of international portfolio expected return both is US Dollar and Indonesian Rupiah are greater than the value of market expected return in international portfolio, as well as the value of market Treynor in domestic portfolio. Thus, it can be said that international portfolio performance from expected return point of view is better than what market has.

As for the Sharpe value of international portfolio both in US Dollar and Indonesian Rupiah are greater than market Sharpe value in international portfolio and market Sharpe value in the domestic portfolio. Thus, it can be said that international portfolio performance is better than the market from Sharpe index point of view. Based on the analysis of expected return and Sharpe presented above, it can be said that international portfolio has better performance than the market.

k. The Effect of International Portfolio on Portfolio Risk 
Based on the observation of Table 6 that contains portfolio variables, the variance value of international portfolio is smaller than the variance value of domestic portfolio both in US Dollar and Indonesian Rupiah. On portfolio denominated in US Dollar, the variance value of international portfolio is $1.075 \times 10^{-5}$, while variance value of domestic portfolio is 0.00026 . On the portfolio denominated in Indonesian Rupiah, the variance value of international portfolio is $1.069 \times 10^{-5}$, while variance value of domestic portfolio is 0.00019 . A smaller variance value on international portfolio indicates that international portfolio bears less risk than domestic portfolio. This is in line with Solnik's (1974) remark that the diversification of the international portfolio will make the portfolio risk smaller than the domestic portfolio.

From systematic risk (portfolio beta) point of view in table 6, the value of international portfolio beta (either in US Dollar or Indonesian Rupiah) is also smaller than domestic portfolio beta value. In accordance with the statement of Buttler (2012) which states that the establishment of an international portfolio will reduce systematic risk that cannot be reduced with the diversification in domestic portfolio.

1. The Effect of Currency Rate on Comparison of International Portfolio Performance and Domestic Portfolio

From the observation and results of analyzes performed, portfolio denominated in US Dollar and Indonesian Rupiah have the same performance trends. International portfolio performance is better than domestic portfolio performance both in US Dollar and Indonesian Rupiah. The existing portfolio variables presented in Table 6 also have the tendency of having similar value. Thus, it can be concluded that the effect of currency (US Dollar or Indonesian Rupiah) on the analysis of international portfolio performance comparison and domestic portfolio performance is very small or almost equals to none.

\section{CONCLUSION}

Based on the analyses performed important points to be considered from this research are: International portfolio performance is better than domestic portfolio performance both in US Dollar and Indonesian Rupiah if it is viewed as portfolio return performance against its risk. This was proven by the higher Treynor and Sharpe values on international portfolio than Treynor and Sharpe values on the domestic portfolio. Meanwhile, if it is seen from return point of view, domestic portfolio performance is better than international portfolio because Jensen value of international portfolio is smaller than Jensen value of domestic portfolio; which indicates that domestic portfolio has greater return than international portfolio. However, it must be taken into account that domestic portfolio has greater risk than international portfolio.

The optimal international portfolio formed in this research has a better performance than its market because the value international portfolio expected return is better than the value of market expected return; in addition to the fact that Sharpe value of international portfolio is better than market Sharpe value. The establishment 
of an international portfolio makes portfolio risk stated in portfolio variance that belongs to international portfolio lower than domestic portfolio risk. The value of international portfolio beta is lower than domestic portfolio beta. The establishment of an international portfolio will reduce the systematic risk that cannot diminish with diversification performed in domestic portfolio (Buttler, 2012).Currency difference between Indonesian Rupiah and US Dollar does not affect the comparison of international portfolio and domestic portfolio performance as the analysis result of portfolio performance both in US Dollar and Indonesian Rupiah shows no different. International portfolio performance is better than domestic portfolio performance.

Recommendation that can be given after the research in the period of testing in 2015 is that Indonesian investors are recommended to form an international portfolio because it has better performance than domestic portfolio. Diversification in the international portfolio can reduce the systematic risk that cannot be reduced with diversification in domestic portfolio. The limitation in this research is in the fact that this research did not considered transaction cost of stocks trading. In addition, this research also did not pay attention to political and economic conditions of countries in the portfolio that can affect stock returns. For further research development, it can be done by using different methods in forming an optimal international portfolio so that methods to form an optimal international portfolio that can be compared. In addition, an international portfolio with stocks from Southeast Asian countries can also be formed to reduce the home bias effect for Indonesian investors.

\section{REFERENCES}

Abidin, S. Z., Ariff, M., Nassir, A. M., \& Mohamad, S. (2004). International Portfolio Diversification: A Malaysian Perspective. Investment Management and Financial Innovations, 3(2004), 51-68.

Buttler, K. C. (2012). Multinational Finance: Evaluating Oppurtunities, Costs, and Risks of Operation. Fifth Edition. USA: John Wiley \& Sons, Inc.

Guesmi, K., \& Teulon, F. (2014). Equity Market Integration and Currency Risk: Empirical Evidence for Indonesia. Working Paper. IPAG Business School Paris.

Hartono, J. 2008. Teori Portofolio dan Analisis Investasi. 5th ed. Yogyakarta: BPFE.

Kang, J. K., \& Stulz, R. M. (1997). Why is there a home bias? An analysis of foreign portfolio equity ownership in Japan. Journal of Finance Economics, 46(1), 328.

Levy, H., \& Sarnat, M., (1970). International diversification of investment portfolios. American Economic Review, 60(4), 668-675.

Lind, D., Marchal, W., \& Wathen, S. (2015). Statistical Techniques in Business \& Economics. $16^{\text {th }}$ ed. United States: McGraw-Hill.

Markowitz, H. M. (1952). Portfolio Selection. The Journal of Finance, 1, 77-91.

Reilly, F. R. \& Brown, K. C. (2012). 10th Ed, Analysis of Investment and Portfolio Management. Canada: Thomson South-Western. 
Sekaran, U., \& Bougie, R. (2013). Research Methods for Business: A Skill-Building Approach. $6^{\text {th }}$ ed. Chicester, UK: John Wiley \& Sons.

Sharpe, W. F. (1964). Capital Asset Prices: A Theory of Market Equilibrium Under Conditions of Risk. The Journal of Finance, 19(3), 425-442.

Solnik, B. H. (1974). Why not diversify Internationally rather than domestically? Financial Analysts Journal, 30(4), 48-54

Solnik, B. H., Boucrelle, C., \& Fur, Y. L. (1996). International Market Correlation and Volatility. Financial Analysts Journal, 52(5), 17-34.

Solnik, B. H. (2000). International Investment, $4^{\text {th }}$ ed. USA: Addison Wesley Longman, Inc.

Tandelilin, E., (2010). Portofolio dan Investasi: Teori dan Aplikasi, $1^{\text {th }}$ ed. Yogyakarta: Kanisius.

Treynor, J. L. (1962). Toward a Theory of Market Value of Risky Assets. Unpublished manuscript. "Rough Draft" dated by Mr. Treynor to the fall of 1962. A final version was published in 1999, in Asset Pricing and Portfolio Performance. Robert A. Korajczyk (editor) London: Risk Books, pp. 15-22

Verma M., \& Hirpara, J. R. (2016). Performance Evaluation of Portfolio using the Sharpe, Jensen and Treynor Methods. Scholars Journal of Economics, Business and Management, 3(7), 382-391. 